\title{
Eduard von Hartmann's Philosophy of the Unconscious
}

\author{
Sebastian Gardner
}

In the second volume of Baldwin's Dictionary of Philosophy and Psychology, published in 1902, the following is given as the entry for the concept "unconscious":

Unconscious (the, philosophy of): Ger. Philosophie des Unbewussten. The metaphysical system of E. v. Hartmann, by whom the absolute principle is called "the Unconscious."

"According to v. Hartmann (Philos. d. Unbewussten, 3) the unconscious is the absolute principle, active in all things, the force which is operative in the inorganic, organic, and mental alike, yet not revealed in consciousness (ibid., 365). It is the unity of unconscious presentation and will (ibid., 380) of the logical (idea) and the alogical (will). The unconscious exists independently of space, time, and individual existence, timeless before the being of the world (ibid., 376). For us it is unconscious, in itself it is superconscious (überbewusst)" (Eisler, Wörterb. d. philos. Begriffe, "Unbewusst"). ${ }^{1}$

This is both a succinct summary of Eduard von Hartmann's leading ideas, and an index of his remarkable historical success - the relevant volume of the Dictionary was published thirty-four years after the appearance of the first edition of the Philosophie des Unbewussten (Philosophy of the Unconscious) in $1868,{ }^{2}$ and at a time when unconscious ideas and inferences had a well established place in psychology, yet Baldwin allows the concept of the unconscious to be identified exclusively with Hartmann's conception of it. ${ }^{3}$

Hartmann's Philosophy of the Unconscious is helpfully regarded as composed of three parts, which Hartmann presents as forming a systematic whole, but which need to be distinguished if we are 
to determine accurately what is historically original in Hartmann's conception of the unconscious. The first part of Hartmann's system consists in a teleological metaphysics of nature, a view of nature (and reality in its entirety) as grounded in a manifold of acts of will or events of willing, unified ultimately under the single act of will or process of willing which he calls the (All-One) Unconscious. The second part is Hartmann's interpretation of this metaphysics as revealing an original synthesis of logical idea and alogical will. Here we find Hartmann claiming a far-reaching philosophical significance for the Philosophy of the Unconscious: it comprises, he claims, an overcoming of the great antinomy formed by Hegel and Schopenhauer which constitutes, in his view, the horizon of contemporary philosophical thought. The third part, based on the second, and which I will refer to as Hartmann's worldview, comprehends everything in Hartmann's system that falls outside metaphysics: his philosophical pessimism, conception of world history and theory of cosmic salvation, his ethical system and religious doctrines, characterisation of the quality of human life, aesthetic theory, and miscellaneous other elements, including much reflection on contemporary public matters and cultural questions. I will take the parts in turn, but spend most time on the first and second.

\section{Hartmann's teleological metaphysics of nature}

1. One of the most striking features of Hartmann's endeavour - one of the respects in which his system appears alien to us, though to his contemporary readers it was in this regard a more familiar kind of enterprise $^{4}-$ is his combination of a metaphysics of absolute idealism with a philosophical methodology which denies anything more than auxiliary value to a priori reflection, ${ }^{5}$ and according to which derivation from experience is the proper source of metaphysical cognition: scientifically processed experience is held to be sufficient to support the most robust metaphysical conclusions, not with complete certainty, yet with a very high degree of confidence. Hartmann calls his method "inductive", although his understanding of this concept is broad, and can be glossed as simply a 
commitment to theorising about the data of experience on the basis of principles of scientific methodology and inference to the best explanation. The importance Hartmann attaches to this methodological innovation is signalled by his sub-title for The Philosophy of the Unconscious "Speculative Results According to the Inductive Method of Physical Science". 6

In terms of his methodology, then, Hartmann is a naturalist, and his further peculiarity lies in his supposition that reflection on the results of the natural sciences is sufficient to warrant conclusions about the ultimate nature of reality which are thoroughly anti-materialist, indeed, which take us all the way to platonic Ideas. Hartmann regards it as a mistake to attach naturalism to materialism: a naturalism that "takes full account of all the results of the natural sciences" will, he says, oppose itself to materialism. ${ }^{7}$

2. How is this co-option of natural science to traditional metaphysical ends to be achieved? Hartmann's strategy has two stages.

The first consists in the application to the organic and psychological realms of a basic and essentially simple argument-schema, which he sets out and defends at the beginning of the Philosophy of the Unconscious. The starting point is provided by direct observations of teleological phenomena and by instances of scientific explanation that have teleological form, i.e. that explain some feature of $\mathrm{X}$ by attributing to $\mathrm{X}$ purposiveness or end-directedness. ${ }^{8}$ The basic question for Hartmann, as for Kant in the "Critique of Teleological Judgement", is what provides for the truth of such statements, and Hartmann supposes that there is only one possibility: namely that $\mathrm{X}$ contains and is determined by an immanent will, which has as its content the representation (or idea) of the end to be achieved. ${ }^{9}$

Hartmann claims that there is no other way of making the observed relation of fit between means and ends intelligible: an explanation that refers only to mechanism leaves the relation miraculous, a case of naked coincidence, while any explanation that instead posits a remote intelligent cause for the mechanism - in deist fashion, on the analogy with a watch designed by a watchmaker - is 
refuted, according to Hartmann, by the intelligent plasticity of function, the indefinitely fine attunement of appropriate means to projected ends that, Hartmann claims, we can observe in the relevant cases. In terms of the watch analogy, it is as if the watch redesigned itself and its mode of functioning as required by changing circumstance, in order to be able to continue to discharge the function of keeping time. So, Hartmann is arguing, the agent of the watch's design, the watchmaker, must be within the watch, not outside and temporally behind it. The cases most amenable to application of this argument schema are of course phenomena in organic nature such as instinctive behaviour, reflex responses, the functioning of internal organs, and reparative processes (worms cut in half regenerating), and these are the sorts of phenomena on which Hartmann focuses in Part (A) of The Philosophy of the Unconscious.

Hartmann does not, however, simply return to a pre-modern conception of teleology as a causality whose operation can be considered independently of any material medium. He assumes - he takes it as a fact established by science - that every instance of teleological causality, including all conscious mental activity, must be realised in efficient material causality. ${ }^{10}$ So wherever there is teleology, there is a corresponding mechanical physiological process, and this latter process is an instance of the unconscious willing of the end which the process serves. ${ }^{11}$

Hartmann also gives a striking application of his argument designed to show that we must admit explanation in terms of unconscious will even in the context where we would least expect it to be needed. ${ }^{12}$ Our own consciously intended actions involve, Hartmann points out, a causal chain running from brain events via nerve fibres to our muscles, and all this neuro-electrical and cellular level causality must, he claims, be conceived on the teleological, X-as-a-means-to-Y pattern. So although it is of course no part of my self-conscious intention, when I raise my hand to wave to you, that this nerve should send that signal to that tendon, the execution of my intention does require that such intentions exist, and these are to be ascribed to sub-centres of my nervous system.

Hartmann is thus not an epiphenomenalist, still less an eliminativist, about self-conscious agency: ${ }^{13}$ his claim is rather that, in terms of the famous distinction drawn by Daniel Dennett, 
explanation of "personal"-level agency forces us to "sub-personal" postulation, and that the postulated sub-personal shares the same (on Hartmann's view) irreducibly intentional structure as the personal.

Tracing out in detail the teleological structure of organic and human nature according to this model occupies many pages of The Philosophy of the Unconscious. Thus in Part (B), "The Unconscious in the Human Mind", ${ }^{14}$ Hartmann applies the concept of unconscious will to the spheres of sexuality and love, ethics, language, art, human history, mystical experience, psychology, epistemology, and so on. In the department of psychology and epistemology, Hartmann argues that mental activity, since it always has a teleological character - acts of memory are strivings to retrieve the past, thought and inference are attempts to formulate true representations, even making associations involves determining the likeness of the terms associated - requires analysis into sub-tasks, just as does bodily action. ${ }^{15}$ Similarly, the (Kantian) conditions of knowledge, categories such as causality and space as the form of intuition, cannot be taken as transcendental givens: according to Hartmann, they involve representational elements which need to be first manufactured, referring us again to purposive unconscious action. ${ }^{16}$

It seems fair to assume that this richness of empirical detail must have been partly responsible for the work's enormous popular appeal - like Fontenelle in the early Enlightenment and popular Darwinian writers in our own times, Hartmann provided a gratifying synoptic overview and integration of natural and human science. (There is more to be said on the topic of Hartmann's popularity, which I will return to at the end.)

3. Now some historical comparisons to bring out what is distinctive in Hartmann's approach to teleology.

Hartmann is in agreement with Kant that there are objectively valid teleological judgements of nature - true statements to the effect that such and such is the function of $\mathrm{X}$, or that $\mathrm{Y}^{\prime}$ s being or acting thus and not otherwise is explained by its having a certain function. Where Hartmann differs from Kant 
is in his fully realistic understanding of these judgements. Hartmann spends no time on the Kantian "Critical” possibility that the objective validity of teleological judgements derives from a subjective necessity of our reason, and that when we consider nature in terms of means and ends we are employing an analogy with our own practical agency, which forbids our taking teleological judgements realistically and obliges us to understand them, in Kant's terminology, as merely regulative. In Kant's terms, ${ }^{17}$ Hartmann is a transcendental realist regarding teleology in nature (and therefore, in Kant's eyes, “dogmatic”).

Second, Hartmann's approach to teleology differs in a fundamental respect from that of Schelling, despite their shared non-Kantian understanding of teleology as not merely regulative of scientific enquiry but constitutive of its object. Schelling's claims regarding the teleological structure of nature are made against a supporting a priori background: Schelling gives a (transcendental) argument that nature and natural phenomena are conceivable only as manifestations of activity and that nature as a whole can be conceived only as a single organism. Hartmann however abjures this a priori reasoning, believing that Schelling's organic, naturphilosophisch conception can be supported wholly a posteriori, and only in that way.

The third contrast to be drawn is with Darwin, whose mechanistic account of teleology in the organic world Hartmann paid much critical attention to - understandably, since Darwinian explanation is the opposite of Hartmann's. ${ }^{18}$ Whereas Hartmann subsumes mechanistic under teleological explanation, grounding instances of mechanical causality in the organic realm on teleological causality, Darwin has teleological description supervening on (a particular kind of) mechanical causality (and where there is no relevant mechanism to which to reduce teleology, there can be no teleology, only an illusion of such). As regards his criticism of Darwin, one of the main points on which Hartmann convicts Darwinism of inadequacy is its lack of explanation for morphological structure and change, the relations of likeness that define species and that exist between different organic types, allowing nature to be apprehended as a systematic set of variations on underlying themes. ${ }^{19}$ 
Hartmann's conception of teleology is thus situated between, on the one hand, the a prioristic and subjectivist conception of Kant, and the a posteriori and realist, but mechanistic, conception of Darwin: in his own eyes, Hartmann is defining a Golden Mean between two one-sided positions (and with regard to Schelling, he takes himself to be improving on a view which is substantially correct but inappropriately supported).

In our eyes, however, it appears rather that Hartmann is attempting to tread a very thin line. His criticism of Darwin is, we can see, extremely weak, for he merely assumes that nature's comprising a chain of being, a rationally patterned taxonomy, is an unquestionable empirical datum and has the status of a primary explanandum. Darwinians of course reject this as a mere appearance that supervenes on a messy mechanistic reality, an example of how our essentialising "folk" biology gets things wrong. This is one of many points where Hartmann appears to lean on and assume the natural-scientific plausibility of metaphysical conceptions and world-images whose origins are remote from modern science, conceptions that the German idealists by contrast regarded as capable of surviving into modernity only if equipped with a transcendental, non-aposteriori foundation. The same point can be made with respect to Hartmann's openly declared commitment to the principle, explicit in Schelling, Schopenhauer and most of German romanticism, that nature's intelligibility is secured by the justified assumption that external nature is essentially akin to us and that we may take ourselves, more exactly our inner experience, to provide the right model for understanding it. ${ }^{20}$ Hartmann appears not to see that adherence to this venerable romantic principle is highly questionable so long as philosophical warrants are required to derive from the sorts of natural scientific a posteriori sources to which he (officially) confines philosophical enquiry. ${ }^{21}$

More generally, Hartmann is clearly open to criticism from mechanistic quarters, in so far as he attempts to establish the necessity of teleological explanation by appealing to the insufficiency of efficient material causes. Thus Friedrich Albert Lange objects that Hartmann is no more entitled to infer a limit to physical explanation from the fact of its current unavailability, than the Australian 
savage is entitled to infer that the spark in a Leyden jar is the work of the devil, and that explanation in terms of the Unconscious exhibits the same lack of intellectual sophistication as primitive animism. ${ }^{22}$ Similarly Franz Brentano indicates the weakness of the premise in Hartmann's argument that our mental performances entail unconscious will, pointing out that only if our knowledge of physiological processes is complete, which we know it not to be, can we infer that physiological processes underpinning mental life have no mechanistic explanation. ${ }^{23}$

4. With the idea of immanent unconscious unities of will and representation established as the explanatory ground of the organic and human realms, we come to the second part of Hartmann's strategy, his attempt to account for the non-organic in the same metaphysical terms. This can be summarised much more briefly. The transition from organic to non-organic is effected in two simple steps. First Hartmann adopts the position (which has a long and honourable history, going back to Leibniz and Kant) that the explanatory basis of the material realm lies in the postulation not of extended substance or mass but of force - matter is properly analysed into atomic points of force, according to Hartmann's “Atomistic Dynamism [atomistischen Dynamismus]”. ${ }^{24}$ Second, Hartmann advances a teleological interpretation of the concept of force as a (simple and immaterial) striving to either attract or repel, and this according to Hartmann is conceptually equivalent to an end-directed will. $^{25}$ The real constitution of non-organic nature thus comprises once again an unconscious unity of will and representation.

In the non-organic realm Hartmann cannot apply the argument schema described earlier, since there is no hint of intelligence in the way that gravity "operates", but he is nonetheless able to employ as a premise the result which he has arrived at in his consideration of organic nature: his argument is that, since we know already that what appears to be mere material mechanism is really (in the organic world) the operation of will, and since we know also that non-organic material phenomena are to be explained in terms of force, the general demand for theoretical economy and uniformity of explanatory 
principles entails that we should carry across the same, volitional, conception of the essence of natural force to the non-organic sphere.

5. One more element needs to be added before we arrive at Hartmann's full concept of the unconscious, namely Hartmann's monism.

The ideas just described are compatible with a pluralistic ontology, an irreducible and underived manifold of distinct unities of will and representation. Hartmann rules out this possibility on the grounds that we, as a matter of fact, find in the natural and human order chains of teleological connection that converge on a single point (to wit: the creation of conscious life in its maximally developed form, that is, human civilization at the extreme height of its possible development). ${ }^{26}$ So again we have an a posteriori argument for a conclusion traditionally derived in a priori fashion. ${ }^{27}$

With all of this in position, we have arrived at Hartmann's concept of the Unconscious - what he calls the All-One Unconscious, as distinct from the plurality of individuated unconsciousnesses that we discover within individual beings (people, ganglions, etc.). ${ }^{28}$ The All-One Unconscious is quite simply that ultimate unity of will and representation which grounds the totality of the phenomena given to us a posteriori as composing the empirical world.

6. Some comments on Hartmann's conception of the unconscious. In the first place, Hartmann has clearly nominalised the concept - it refers to an individual, a substance (indeed, the only individual and substance). Previous romantics, with the exception of Carus, ${ }^{29}$ had not consistently employed the concept of the Unconscious, in place of other concepts such as Leben or the Absolute, to indicate the One-and-All.

As regards his differences from Carus, there is at least the difference that Carus does not appeal to the same extensive body of natural scientific evidence as Hartmann. ${ }^{30}$ Hartmann's innovation was therefore to recruit a mass of scientific material which would appear to be the rightful property of 
mechanistic materialists in the mould of Helmholtz, in support of ideas associated with naturphilosophisch thinkers like Schelling and Carus. Depending on which angle one considers it from, this development is either a case of making Naturphilosophie properly "scientific" (Hartmann's own view), or a misappropriation that betrays a culpably erroneous understanding of the nature of science (the view of Hartmann's many critics), or a travesty of Naturphilosophie that cuts it off from its true sources (the view of Hartmann from an orthodox naturphilosophisch standpoint).

In any case, to this extent Hartmann's unconscious is certainly original. But it is notable that Hartmann does not have an innovative conception of the nature or constitution of what he calls the Unconscious: his whole emphasis is, on the contrary, on its continuity, on the identity of its constitution, with the two fundamental classes of phenomena grasped in ordinary consciousness, namely will and representation. ${ }^{31}$ What Hartmann has to say conceptually about the intrinsic nature of the unconscious draws from ordinary thought, and he does not claim that with its discovery we enter a new and unfamiliar kind of territory: certainly we come upon new ground, but the landscape is of the sort that is before our eyes all the time - it does not display a new set of laws, has no oneiric aspect, and certainly does not amount to an irrational or unintelligible realm beyond the reach of discursive thought. ${ }^{32}$ On the contrary, what strikes us most, Hartmann insists, is its display of "rational intelligence [die vernünttige Intelligenz]". ${ }^{33}$ In this sense Hartmann's conception is conservative, not innovative. $^{34}$

Matters are admittedly a bit more complicated, for although what I have just said applies straightforwardly to the unconscious as multiply individuated, the unconscious as described in Parts (A) and (B) of The Philosophy of the Unconscious, it does not apply so straightforwardly to the AllOne "absolute" Unconscious of Part (C). Thus Part (C) opens with an account of how the Unconscious differs from consciousness. The chief differences stated by Hartmann concern (i) the form of representation: conscious representation is sensory, representation in the Unconscious is non-sensory or intellectual-intuitive; ${ }^{35}$ (ii) temporality: the form of existence of conscious mental activity is temporal, 
that of the Unconscious is non-temporal; and (iii) the relation of will and representation: will and representation "are united in inseparable unity [in untrennbarer Einheit verbunden]" in the Unconscious ${ }^{36}$ whereas consciousness is able to entertain representations without willing their realisation. ${ }^{37}$

These differences are certainly metaphysically deep. But two points need emphasis. First, the differences cited leave untouched the basic identity of the mode of functioning of consciousness with that of unconsciousness, namely the means-end principle of practical reason. Second, what motivates Hartmann to ascribe these differentiating characteristics to the Unconscious are exclusively philosophical considerations deriving from Hartmann's interest in raising the Unconscious, as it emerges from his "inductive" reflections on nature, up to the status of the Absolute as conceived in monistic objective idealism, in preparation for the worldview that Hartmann will then base on this metaphysics.

This point can be sharpened by considering Hartmann in the light of a well-known conceptual point made by Freud in his metapsychological writings. Every introduction of a concept of the unconscious in a theoretical context, whether psychological or philosophical, stands in need of justification, and this must of course have to do with gains of explanation, whether transcendental (as in Schelling) or empirical-psychological (as in Freud). But the designation "unconscious" does not of itself identify a property which turns any explanatory wheels: it merely creates a space for the postulation of something that will do explanatory work, by lifting the epistemological barrier to its postulation set by the item's non-existence in consciousness. Thus Freud insists that the interest of psycho-analysis lies not in its employment of unconsciousness in a merely descriptive sense - which, he notes, is old hat - but in its novel systematic conception of the formation, content and causality of the unconscious. And it is often observed that in Freud's metapsychological writings the property of unconsciousness, and appeal to mental processes defined in terms thereof, such as repression, become over time less important for psychoanalytic explanation, and that other concepts, defined with 
indifference to their conscious/unconscious status, such as phantasy, assume more of the explanatory burden.

There is a further point to be made concerning the contrast of Hartmann with Freud. One of the most philosophically interesting features of psychoanalytic theory concerns its conception of the (metaphysical, non-epistemological) relation of the unconscious to the "I" of self-consciousness and to the person as opposed to the mere human organism. The question is this: Granted that I have no direct knowledge of the contents of my unconscious, can these contents nevertheless be thought to be mine, a part of me, to belong to me, with all that this apparently entails? ${ }^{38}$ Whatever the right answer to this question may be ${ }^{39}$ it seems to me beyond doubt that psychoanalysis, correctly understood, precludes our thinking of unconscious contents as straightforwardly extra-personal (in the way that my vital organs are external to my personality). Hartmann however does claim exactly this extra-personal status for the Unconscious: he writes, I may be proud of the work of consciousness, as my own deed, but "the fruit of the Unconscious is as it were a gift of the gods, and man only its favoured messenger". ${ }^{40}$ Hartmann is not alive to the deep and difficult issue concerning the borders of selfhood with which psychoanalysis is engaged on both its theoretical and practical-therapeutic fronts.

Do these various point reveal a limitation of von Hartmann's philosophy? They might well be regarded as such, if Hartmann's philosophy were pretending to offer original conceptual materials with which to understand ourselves and the world, or if our measure of the progressiveness of a conception of the unconscious were the degree to which it anticipates the Freudian conception. But neither of these provides the right understanding of Hartmann, whose concerns are in no way proto-Freudian, ${ }^{41}$ and who makes no claim for his own fundamental originality - Hartmann's emphasis is always on the way that the materials that he is using have already been worked out and lie ready to hand, ${ }^{42}$ his own role being that of a re-organiser of previously tried-and-tested elements. ${ }^{43}$ Where he locates his own original philosophical achievement is (in addition to his methodological combination of science with philosophy) in the synthesis of Hegel and Schopenhauer, to which I now turn. 


\section{Hartmann's theory of an original synthesis of Idea (Hegel) and Will (Schopenhauer)}

1. The notion of a synthesis of Hegel and Schopenhauer sounds at first blush bizarre and unpromising, but it is important to recognise that, in the light of Hartmann's guiding preoccupations, it has sound

motivation. Hartmann shared with certain other late nineteenth-century German philosophers - among whom may be included Eugen Dühring, Julius Bahnsen, Julius Frauenstädt, and Johannes Volkelt - a broad approach to philosophical enquiry which set them apart from the dominant schools of neokantianism, and which typically involved taking not Kant but rather Hegel, Schelling and (especially) Schopenhauer as primary historical points of reference. On this basis they pursued what can only be described as the unfinished business of German idealism - the argument of Schelling with Hegel, and the (to some extent parallel) argument of Schopenhauer with Fichte, Schelling and Hegel. Their motive for picking up the threads from the first half of the nineteenth century - the reason why those who belonged to the same philosophical tendency as Hartmann directed their concern to earlier idealist thinkers whose reputation, it must be remembered, was far from high post-1850 - lay in the way that, so it seemed, the central metaphysical issues in German idealism allowed nebulous questions of Weltanschauung and post-Christian life-orientation, of optimism and pessimism, to be pursued fruitfully. Hartmann's Hegel-Schopenhauer synthesis was calculated, therefore, not primarily to resolve problems of metaphysics, but rather to facilitate a fully comprehensive view of human life, specifically, a unity of optimism and pessimism. ${ }^{44}$

2. What does Hartmann's metaphysical synthesis consist in $?^{45}$

If we took Hartmann's teleological metaphysics of nature - the part of his system considered so far - in isolation and asked what it shows regarding the ultimate nature of reality, what we should then expect him to say, is that will and idea (representation), although conceptually distinct, form a 
primordial unity: in other words, that with respect to the ultimate ground of reality, viz. the absolute Unconscious, the will/representation distinction is a rational or modal but not a real distinction.

Hartmann's view would then be, that what is ontologically basic is a primitive and undecomposable purposive-striving, from which the concepts of "will" and "understanding" are abstractions. Hartmann, since he eschewed transcendental reflection, could not have followed Fichte and Schelling in taking it that "activity" - intentional, goal-directed activity - is a conceptual primitive in philosophical thought, but he could still have treated it as an ontological primitive, and his insistence on so many pages of The Philosophy of the Unconscious that will and idea are "inseparably united" seems to demand exactly this view.

Had Hartmann followed this pattern, then his system would have been little more than an attempted restatement on a posteriori grounds of Schelling's Naturphilosophie. But this is not his view. Instead, Hartmann declares that Will and Idea (representation) are in themselves and at the most fundamental ontological level - meaning: not in the world, but in the pre-mundane grounds of the world - absolutely distinct, absolutely independent, and absolutely heterogeneous. In addition, influenced heavily by the later Schelling, Hartmann associates each of Will and Idea with the two basic and primordially distinct dimensions of all things: Will corresponds to the "Daß" (that) of things, the dimension of sheer existence, and Idea to the "Was" or "Wie" (what or how) of things, the dimension of essence. ${ }^{46}$

This primordial dualism must be overcome, of course, in order for the existence of the world and the Unconscious which is its ground to be possible, but this need for supplementary explanation is for Hartmann not a problem, for it allows him to introduce an explanation of the world's coming-to-be from which it follows (so he claims) that the world ought not to be. On this basis Hartmann can then present the soteriological doctrine with which his Philosophy of the Unconscious is famously associated: his idea that the existence of the world is a mistake, and that the final purpose of natural and human history is its rectification, through the development of a collective human consciousness which, 
upon achieving insight that the world ought not to be, brings itself and the world to an end, thereby liberating the Idea from the Will, and returning reality to its initial state. ${ }^{47}$ The world is thus only a device for cancelling the original synthesis of Will and Idea.

In this way, Hegel and Schopenhauer are synthesised, and shown to have each grasped one side (but only one side) of the truth: Hegel is right that the world and its history is the realisation of the Concept, and Schopenhauer is right that the world as representation is a manifestation of Will which, regarded for what it is intrinsically, is purposeless. Hegelian "optimism" regarding the world is squared with Schopenhauerian pessimism: ours is the best of all possible worlds and yet its very existence is the worst of all metaphysical possibilities (as is the existence of any world, since all worlds presuppose the fusion of Idea and Will). And Hartmann's collective version of Schopenhauer's individualist denial of will can be identified with the consummation of rationality in collective human existence which marks the Hegelian end of history.

3. From a systematic philosophical point of view, the interesting question is whether Hartmann's synthetic proposal is successful by his own lights: since if Hartmann is right that the pressure of the opposition of Hegel and Schopenhauer forces us to embrace its rational resolution in the Philosophy of the Unconscious, then Hartmann's system must be considered the consummation and true culmination of German idealism.

The decisive issue concerns the story that Hartmann tells about how the original metaphysical mistake, the original "fall" of Will and Idea which forms the Unconscious and creates the world, takes place. His account, he acknowledges, draws extensively on late Schelling, whom he considers to have come closer than anyone to the correct synthetic view (but to have failed to bring his insights to a consistent final form, on account of his apriorism and his inability to shake off his attachment to prescientific, especially Christian, forms of thought ${ }^{48}$ ). 
Hartmann describes Idea as something that is properly pre-ontological, ${ }^{49}$ and Will as a potentiality-for-willing ${ }^{50}$ which, on account of its character as pure object-less striving, experiences its existence as pain, from which it attempts to free itself by uniting itself with Idea - as if through taking on conceptual structure, the Will could gain for itself a determinate goal, which it could then realise, thereby making the transition from painful longing to pain-free fulfilment. The upshot however is only that the eternal bliss of the Idea - its "absolutely self-sufficient peace [ewigen Ruhe ihres Fürsichseins]" ${ }^{, 51}$ - is destroyed. In Hartmann's figurative or mythological presentation of the philosophical story, the seizing of the female Idea by the male Will is pictured as a sexual act, which issues in the birth of the Unconscious. This child produces the world and determines its history, however, with no other aim than that of undoing the mistake of its own original conception. ${ }^{52}$

4. Without going further into the detail of Hartmann's synthetic story, it is possible to see why his speculation, for all that it exhibits ingenuity and indisputable metaphysical originality, must be regarded as unsuccessful.

(a) First, there is the matter of epistemology. On what basis can we know (or even just hold it to be probable) that behind the Unconscious lies an original dis-unity of Will and Idea? Our empirically grounded knowledge appears to stop at the fact of their necessary unity - this fact constitutes "the apex of the pyramid of inductive knowledge" $" 53$ - and Hartmann eschews a supra-empirical method of intellectual intuition. So the teleological metaphysics of nature does not motivate the theory of an original synthesis of Will and Idea.

Hartmann's answer is that there is indirect empirical evidence of original dis-unity. This has an unusual source: it stems, according to Hartmann, from our experience of dissatisfaction with our own place in and relation to the world. Hartmann supposes that it is a necessary part of the experience of being conscious, that the world is experienced as failing to measure up, and that this serves us as a metaphysical clue: if the world is not "as it should be", then there must be some idea in the light of 
which it is so judged. It seems Hartmann is right that, if the datum that the world "falls short" were established firmly, then there would be some ground for inferring backwards, for going behind the back of the empirically given and comprehended world, to the original disharmony and hence distinction of Will and Idea which he hypothesises. The problem, however, is that Hartmann's account of the world's "failure" by the light of conscious experience is shallower and considerably less impressive than that of, say, Kant, who can appeal to our knowledge of the transcendence of Nature by Reason in various spheres (of theoretical reason, morality, the sublime and so on) as grounds for thinking that the empirical world lacks full reality and that a noumenal realm must be posited in addition. Hartmann by contrast appeals exclusively to hedonic considerations - the empirically discovered preponderance of pain over pleasure in human life - and this, surely, is something for which plain, non-speculative, naturalistic (e.g., evolutionary) explanations are easily available. ${ }^{54}$ So a compelling epistemological basis for Hartmann's synthetic theory is lacking.

(b) The metaphysical difficulties start with Hartmann's dualism of fundamental principles. In Descartes' metaphysics - which, it may be noted, Hartmann himself criticises for its dualistic character ${ }^{55}$ - mind and matter both fall under the concept of "created substance". With Hartmann's Will and Idea, by contrast, there is no higher category under which both can be brought, not even that of "existences": Will and Idea are regarded as alien to one another in all thinkable respects. Nor can the relation into which they are brought through their synthesis be rationalised in the way that Spinoza identifies mind and body as double attributes of a single substance, or in the way that Schelling's identity philosophy conceives subjectivity and objectivity, ideality and reality, as different powers of a single indifference point. Nor, again, are Will and Idea contrasted by Hartmann, as they are in Schopenhauer, as reality and appearance. Hartmann's dualism thus goes all the way up, ${ }^{56}$ and in consequence there is an aporia concerning how it is possible for anything whatever, let alone a third thing in which Will and Idea are "inseparably united", to derive from the original dualism. ${ }^{57}$ 
(c) Even if this difficulty is held aside, and the sheer possibility of an ontological fusion of absolutely heterogeneous elements is allowed, the synthesis of Will and Idea envisaged by Hartmann encounters a further problem, on account of the specific character of the elements synthesised (a problem of content, as opposed to the previous, purely formal problem). Hartmann insists that the philosophical principles expressed by Will and Idea are, respectively, the logical or rational, and the alogical or anti-logical or irrational. ${ }^{58}$ This characterisation, note, is essential for Hartmann's claim to have united Hegel and Schopenhauer: the contrast of Will and Idea cannot be merely of Existence and Reason, for this would take Hartmann only as far as late Schelling, and Hartmann denies that late Schelling provides an Aufhebung of the Hegel-Schopenhauer antinomy. ${ }^{59}$ But this immediately suggests a paradox. Under what concept are we to bring (how are we to think) the synthetic unification of Will and Idea? Hartmann wants us to think of it as a mistake - as something that ought not to have happened (or "been done"). ${ }^{60}$ But to say this is evidently to situate the event within the space of reasons and so to give priority to reason, the Idea, over Will. ${ }^{61}$ In fact, the details of Hartmann's synthesis story imply this directly: he suggests that Will commits an error of judgement in incarnating itself, which implies that Will is engaged in practical reasoning, which means in turn either that Will and Idea are not primordially independent, or that Idea (reason) is prior to Will. ${ }^{62}$ If, however, Hartmann were to withdraw his description of the event as a mistake, or even just set this description in inverted commas, then the grounds for pessimism - for thinking of the world as something that ought not to be, the product of an event that ought not to have occurred - would disappear. (And at this point it should be remembered that, as indicated above, pessimism is a necessary epistemological premise of the synthetic theory: the badness of the world is the only reason we have for thinking that Will and Idea are originally dis-united.) More generally, it seems that whatever concept we employ to conceive the unification of Will and Idea must belong to and derive from either the sphere of Idea or that of Will. If the former, then we are back to a kind of Hegelianism. If the latter, then we have a victory for Schopenhauer over Hegel, and therefore still nothing that bears out Hartmann's claim to have provided 
a synthesis of the two systems, and furthermore nothing that shows the world to be something that ought not to exist, since if Will's unification with Idea has no description in the language of reason, then it is just something that happens - an absolute contingency, with regard to which all normative assessment is out of place.

The problem, in other words, is that although Hartmann denies that there is any higher unity of Will and Idea, and affirms only their lower, derivative unity in the Unconscious, we are required to position ourselves in philosophical reflection beyond the original dualism, and to think that duality as a unity, in so far as we attempt to grasp the story that Hartmann tells of how Idea and Will are originally confounded; and in thinking this unity, it is necessary, moreover, for either Will or Idea to predominate. (Schelling himself, it may be noted, does not come to grief in this way: the claim of Schelling's identity philosophy of 1802-03 is precisely that final dualities cannot be co-thought in terms other than those of absolute indifference/identity; and in the accounts that Schelling gives later, from the Freiheitsschrift of 1809 onwards, Will has priority over Idea, Vernunft.)

This paradox - an indication that Hegel and Schopenhauer are, after all, not contraries but rather contradictories - represents, I suggest, the fundamental incoherence in the Philosophy of the Unconscious, but it is reflected at many other points further down the line where Hartmann can be charged with failing to achieve coherence. For instance: Hartmann maintains that the "proper motive and main purpose [eigentliche Kernpunct und nächste Zweck]" of the creation of consciousness is the independence that it permits of Idea from Will (which is essential for the world's salvation). ${ }^{63}$ This is one of the deep points of differentiation allowed by Hartmann of the conscious from the Unconscious: consciousness can entertain representations without also willing them, the Unconscious cannot. The purpose of creating consciousness, Hartmann notes, "would be absurd [wäre aber widersinnig]" consciousness would be "superfluous [überflüssig]" - if the Unconscious as such already contained the possibility of the emancipation of Idea from Will. ${ }^{64}$ But it appears that exactly this possibility must be contained in some form in the Unconscious, in order for the idea of the intellect's independence from 
the will to figure as a content of the Unconscious' intention. If Idea and Will "are united in inseparable unity [in untrennbarer Einheit verbunden]" in the Unconscious, it is unexplained how the Unconscious can form or even entertain as coherent the possibility of either's existing independently of the other; ${ }^{65}$ to do so would require the Unconscious to think about itself in counterfactual terms, and possession of this capacity would entail the independence of intellect from will which, according to Hartmann, only consciousness possesses.

Many other points at which it is reasonable to allege incoherence in Hartmann's synthesis story were pointed out by his contemporaries, ${ }^{66}$ but I will here end the discussion of its metaphysical difficulties.

(d) Finally, some comment is due on Hartmann's attempt to situate his Philosophy of the Unconscious historically, since this forms an important part of his argument. The motivation for Hartmann's theory of synthesis, according to his presentation of it, depends to a considerable degree on the inadequacy of the alternatives as Hartmann sees them, namely, the philosophical systems of early Schelling, Hegel, Schopenhauer, and late Schelling. A review of everything that Hartmann has to say about these philosophers would take a good deal of space, ${ }^{67}$ so I will restrict myself to two observations. First, Hartmann needs to proceed with considerable care in his criticism of his predecessors, since if the strength of his objection rises above a certain level, then it will seem that the right conclusion to draw - and that had been drawn, of course, by the overwhelming majority of Hartmann's contemporaries - is that the whole project of idealistic system-building is ill-conceived, and that philosophy must follow some other (neo-Kantian, materialist or whatever) path. Given the severity of Hartmann's misgivings about the design and foundations of his predecessors' systems, it is not at all clear that this condition is met. The particular danger, of course, is that, in endorsing Hegelian criticisms of Schopenhauer, and Schopenhauerian criticisms of Hegel, Hartmann will merely succeed in showing how each cancels the other out, leaving nothing behind to build upon. 
Second, in so far as we agree with Hartmann that the salient historical legacy is the HegelSchopenhauer antinomy, and that its resolution defines the present task of philosophy, the direction in which we are pointed is no doubt, as Hartmann says, late Schelling. A lot hangs therefore on Hartmann's criticisms of Schelling's late, "positive”, philosophy. If Hartmann's alternative to late Schelling proves incoherent, then Schelling's position is vindicated as representing the furthest that one can or need go in the direction of accommodating the reality of the extra-logical from an absolute idealist standpoint.

5. I have argued that Hartmann's system divides, on the one hand, into a monistic teleological metaphysics of nature - which has some degree of originality and which, whatever its weaknesses, at least hangs together coherently - and on the other, a dualistic synthetic theory, which is highly original but unsuccessful. For this last reason, Hartmann is not usually numbered among the great absolute idealists: philosophers who are interested from a systematic point of view in post-Hegelian developments in absolute idealism typically turn to the British and American idealists, without stopping to look at Hartmann. The third part of Hartmann's system, the worldview, collapses along with the synthetic theory.

We may now ask what has gone wrong at bottom in Hartmann's philosophical endeavour. It is natural for us, in view of our present-day philosophical outlook, to suppose that the root problem with Hartmann must lie in his attempt to yoke together the contradictory positions of naturalism on the one hand, and idealism on the other; and it is generally true that the interaction of naturalistic and nonnaturalistic - idealist, transcendentalist - elements is responsible for much in, and can explain many of the distinctive features of, late nineteenth-century German philosophy. This assessment of Hartmann is, however, not straightforwardly correct. As regards the naturalism/anti-naturalism opposition, Hartmann is quite clear where he stands: he is on the side of idealism, and he is furthermore right to think that absolute idealism is capable of supporting an image of reality that integrates the results of natural 
science with metaphysics and that coincides on some points with naturalism, as it does in Schelling and Hegel. And while it is true, or so I suggested, that Hartmann's naturalistic methodology renders his position weak as regards its justification, it does not render it incoherent. The "naturalism vs. idealism" opposition is not, therefore, the proximate source of Hartmann's problems.

Instead, one might seek to lay the blame for the infelicity of Hartmann's system on the nonCritical character of his realism - his rejection of, or indifference to, the whole transcendental idea that metaphysical speculation needs to be conditioned by reflection on the conditions under which metaphysical knowledge is possible, and that speculation which is not shaped in that way puts itself at the mercy of transcendental illusion and thus tends to incoherence. On this account, Hartmann's problem is his imperfect, epistemologically naive appropriation of the idealist legacy. ${ }^{68}$

This would be a standard Kantian or German idealist critical take on Hartmann. However, and aside from the fact that this explanation will seem correct only to those have faith in the original idealist project, it seems unlikely that this is the whole story, for we should still want to know why Hartmann decided against taking up the transcendentalist orthodoxy, his departure from which cannot be reduced to a mere misunderstanding. In the next section I will suggest that, when we reflect on the reception of Hartmann's ideas, another and more interesting diagnostic possibility comes into view.

\section{Hartmann's worldview and its positive reception}

Hartmann's extraordinary popular success was recognised as puzzling (and deplored) by his neoKantian contemporaries. Lange writes:

[I]t remains a remarkable fact that so soon after the campaign of our Materialists against the whole of philosophy, a [Hartmann's] system could find so much acceptance, which opposes itself more decidedly to the positive sciences than any of the earlier systems, and which in this 
respect repeats all the errors of Schelling and Hegel in a much coarser and more palpable shape. ${ }^{69}$

Windelband too describes the Hartmann phenomenon, with a hint of exasperation, as a "remarkable and serious [verwunderlicher und bedenklicher]" matter. More precisely, Windelband suggests that whereas the historically earlier positive reception of Schopenhauer's pessimism can be attributed to social and political circumstance - the disappointment of expectations of liberal reform - the wave of philosophical pessimism which followed in Hartmann's wake in the 1870s has no such excuse, and he goes on to describe the manner in which Hartmann's "brilliant but misleading [blendende und verblendende]" Philosophy of the Unconscious achieved domination of popular philosophical literature, as "a manifestation of relaxation and surfeit [eine Erschlaffungs- und Uebersättigungserscheinung]" at the present stage of civilisation. ${ }^{70}$

Windelband's suggestion of decadence surrounding the Philosophy of the Unconscious certainly has the ring of truth, but if we are to regard it as anything more than an extrinsic matter, pertaining to the circumstances of Hartmann's reception but not to the content of his thought, then we need to nail down more precisely what it is in virtue of which his philosophy might be considered an expression of cultural decay.

Now one of the most striking dimensions of Hartmann's Philosophy of the Unconscious which I have left until last - concerns its purported practical, ethical and religious upshot. I said earlier that the late nineteenth-century tendency to which Hartmann belongs was guided by a concern with "life orientations", ${ }^{71}$ and Hartmann expressed confidence that the Philosophy of the Unconscious would answer to man's religious needs, which he regarded as abiding, legitimate, and neglected by the philosophies of his contemporaries, even entertaining the hope that the Philosophy of the Unconscious would help to elicit the formation of a new religion. ${ }^{72}$ However, I think it is clear to all readers of Hartmann that the Philosophy of the Unconscious fails utterly in this respect. It simply has no 
existential grip. In stark contrast to his idealist predecessors, Hartmann's metaphysics fail to give articulate form to anything deep in the human situation.

In support of this judgement, consider first the way in which Hartmann's practical philosophy demands a total self-transcendence for which no intelligible motivational root is (or can be) provided. Hartmann requires us to take up directly the point of view of the universe - indeed, a point of view before the metaphysical beginning of the universe - and to identify, as constituting the Good for us, the welfare of an "object", the Idea, to which not even existence can be attributed. ${ }^{73}$ Hartmann's argument for this conception of the Good proceeds by elimination, but what he seems to fail to recognise is that, if the elimination of all other candidates for the final purpose of mankind leaves nothing but the beatitude of the Idea, then the more plausible conclusion to be drawn is that human beings are in fact without any purpose whatever: we may as well accept the instruction to concern ourselves with, or be reassured to learn that our lives ultimately contribute to, the happiness of the system of natural numbers, as affirm that human history will achieve its inherent end when it has allowed conceptuality to withdraw from nature. Hartmann simply does not see how remote his proposal lies from the comparatively more intelligible, reflexively contentful and existentially engaged forms of selftranscendence urged by Spinoza, Schelling, and Schopenhauer.

Nietzsche's assessment of Hartmann in Beyond Good and Evil draws the contrast between the type of philosopher found among the ancients - a Heraclitus, Plato, or Empedocles - and contemporary representatives of philosophy such as the "Amalgamist" Hartmann, who find themselves, "thanks to fashion, as much on top as they are really at the bottom". ${ }^{74}$ The latter, Nietzsche says, are

all losers who have been brought back under the hegemony of science, after having desired more of themselves at some time without having had the right to this "more" and its responsibilities - and who now represent, in word and deed, honourably, resentfully, and vengefully, the unbelief in the masterly task and masterfulness of philosophy. ${ }^{75}$ 
The late nineteenth-century, post-Schopenhauerian optimism/pessimism debate, with which Hartmann is so deeply preoccupied, Nietzsche dismisses elsewhere as a "priestly squabble [Pfaffenstreit]". ${ }^{76}$ Though Nietzsche's standards for a genuine philosophical spirit are higher than most and his conception of the task of philosophy is far from orthodox, Nietzsche's estimates are persuasive: while certainly the echo can be heard in Hartmann of a truly deep and demanding philosophical task, the way that Hartmann has tried to execute it shows it to have been drained of genuine import. The existential roots of the optimism/pessimism debate lie in the antinomial experience which we have of the distinctness and irreconcilability of, as Wittgenstein put it, the worlds of the happy man and the unhappy man, and in the practical necessity of life in the face of suffering, to which corresponds the practically motivated philosophical task of answering the objection that suffering puts, or appears to put, to life. Whereas Nietzsche devoted his philosophical endeavours to defining a standpoint which could claim to have genuinely transcended the antinomy and answered the objection, Hartmann handles the issue of Optimism vs. Pessimism in merely wissenschaftlich terms, as if it were merely an opposition within theoretical reason that simply poses a formal problem for the construction of a systematic, "scientific" conception of reality - a conflict of two rival natural-scientific or metaphysical hypotheses concerning the nature of the world.

And yet, Hartmann's Philosophy of the Unconscious, instead of falling stillborn from the press, captured Europe's imagination. ${ }^{77}$ Why did this happen?

Hartmann's pessimistic worldview had its appeal, it may be supposed, pursuing Nietzsche's suggestion, not in spite of but because of its failure to turn any genuine motivational wheels in its readership: it answered to a state of deep dissatisfaction in European high culture by furnishing a representation, a Weltbild, to which that diffuse negative affect could attach itself, and in which it could be felt to have received expression, but it did so without bringing to light, and it even served to deflect insight into, the real causes or grounds of the malaise. The practical and existential nullity of 
Hartmann's ethics and "religion", the fact that in reality it demands nothing from us, reflects his philosophy's function of passively certifying, without interrogating or genuinely putting to the test, the discontent of European high culture. In this way it is appropriate to regard the Philosophy of the Unconscious as a symptom in the Nietzschean-Freudian sense.

It seems fair to conclude that, contrary to Hartmann's order of presentation of his ideas, what fundamentally determines the structure of his thinking is his worldview, and that his appropriation of absolute idealist metaphysics to the end of promulgating a Weltanschauung which in fact repudiates, even more thoroughly than Schopenhauer, all of the basic and inspirational elements of German idealism - its commitment to freedom, autonomy, subjectivity, self-consciousness - is what is ultimately responsible for the skewed character of the Philosophy of the Unconscious. In this more subtle sense, there is arguably some truth in the idea that Hartmann manifests the unresolved contradiction, which runs through nineteenth-century German philosophy, of naturalism and antinaturalistic idealism. Be that as it may, as regards the history of the concept of the unconscious, the byproduct of Hartmann's endeavour was a conception of the unconscious more sober, more systematically elaborated, and considerably closer than its ancestors in Romantik and Naturphilosophie to modern materialistic-mechanistic science. In this way, though quite independently of his intentions, Hartmann indisputably helped to prepare the way for Freud.

${ }^{1}$ James Mark Baldwin, Dictionary of Philosophy and Psychology (New York: Macmillan, 1901-05), vol. 2 (1902), 724-5.

${ }^{2}$ The full title of the work is Philosophie des Unbewussten. Speculative Resultate nach inductivnaturwissenschaftlicher Methode (original sub-title, in 1st edn [Berlin: Carl Duncker, 1869]: Versuch einer Weltanschauung). A second and enlarged edition appeared in 1870, and many further editions 
appeared in response to public demand for several decades; the 11th edition of 1904 was the last published in Hartmann's lifetime.

References to the Philosophy of the Unconscious ("PU") are to the single-volume Kegan Paul (London) edition of 1931 (with a preface by C. K. Ogden), which is based on the three-volume authorised English translation of 1884 by William Chatterton Coupland (from the 9th German edition of 1882). (A more recent edition, in 3 volumes and repaginated, is available from Living Time Press [Shrewbury, UK, 2001-2002].) References take the form, e.g., "PU I (B), 220”, referring to VolumeDivision I, Part (B), page 220. References in square brackets are to the (12th) German edition, Philosophie des Unbewussten. Speculative Resultate nach inductiv-naturwissenschaftlicher Methode, 3 Bde. (Leipzig: Alfred Kröner, 1923), and take the form, e.g., “[I (B), 190]”: Band I, Teil (B), Seite 190. ${ }^{3}$ Sonu Shamdasani has pointed out that Baldwin's own antipathy to the concept of the unconscious is likely to have played a role, Baldwin's intention being to damn by association.

${ }^{4}$ In Rudolf Hermann Lotze, too, natural science and metaphysics are brought close together, and an absolute idealism is advanced on a regressive, non-deductive basis. Eugen Dühring and Hans Vaihinger also combine naturalism with metaphysics.

${ }^{5}$ Hartmann has no single justification for his rejection of the a priori but instead argues on a case by case basis; see e.g. Schelling's philosophisches System (Leipzig: H. Haacke, 1897), ch 2. 6 "Speculative Resultate nach inductiv-naturwissenschaftlicher Methode”, Hartmann's "Motto": PU I, $13[\mathrm{I}, 11]$.

7 “welche allen Resultaten der Naturwissenschaften volle Rechnung trägt”; PU II (C), 63 [II, 17].

${ }^{8}$ See PU I, 43-5 [I, 36-7].

${ }^{9}$ See esp. PU I (A), 98 [I (A), 84] and 113-14 [I (A), 112-13], and PU II (C), ch. VIII.

${ }^{10}$ Hartmann is in this sense a materialist, in so far as he accepts the principle that all conscious mental activity can come to pass only by normal function of the brain (PU II (C), 64 [II (C), 18]), and 
"cerebral vibrations, more generally material movement [Gehirnschwingungen, allgemeine die materielle Bewegung]" as conditions of consciousness (PU II (C), 80 [II (C), 31]; see also PU II (C), ch. II). Hartmann's metaphysics of the mind-body relation involves therefore three levels: (1) conscious mental activity, which reduces to (2) brain function, which reduces in turn to (3) unconscious will. ${ }^{11}$ E.g. PU I (A), 123-4 [I (A), 106]: when the ganglionic will wills to contract the cardiac muscle, it must possesss the idea of this contraction, "for otherwise God only knows what could be contracted, but not the cardiac muscle [denn sonst könnte weiss Gott was contrahirt werden, nur nicht der Herzmuskel]". See also PU I (A), 69-70 [I (A), 59-60].

${ }^{12}$ The argument is summarised at PU I (A), 77 [I (A), 66-7].

${ }^{13}$ See PU I (A), 138 [I (A), 118].

14 "Das Unbewusste im menschlichen Geiste".

${ }^{15}$ See PU I (B), 301ff [I (B), 261ff].

${ }^{16}$ See PU I (B), 304ff [I (B), 264ff], and PU I (B), ch. VIII.

${ }^{17}$ And in his own terms: see PU I, Addenda, 323-6 [I, Nachträge, 490-2], where Hartmann claims that the objects of natural science qualify as things in themselves, and PU I (B), 329-30 [I (B), 285], on the transcendental reality of empirical objects. See also Kritische Grundlegung des transcendentalen Realismus (Berlin: Carl Duncker, 1875). For an exposition and criticism of Hartmann's epistemology, see W. Caldwell, “The epistemology of Ed. v. Hartmann”, Mind 2 (1893): 188-207.

${ }^{18}$ See PU I (B), 287-8 [I (B), 248-9], and at greater length, Wahrheit und Irrtum im Darwinismus. Eine Kritische Darstellung der organischen Entwicklungstheorie (Berlin: Carl Duncker, 1875) [Parts I-II translated as "The True and the False in Darwinism: A Critical Representation of the Theory of Organic Development”, Journal of Speculative Philosophy 11 (1877-78): 244-51 and 392-9]. ${ }^{19}$ See Wahrheit und Irrtum, 8-9 ["The True and the False in Darwinism", 248-9], and PU II (C), ch. X, esp. 306-7 [II (C), 229-30]. At PU I (B), 287-8 [I (B), 248-9], Darwin is said to explain the 
transmission of features (capacities), but not their existence (their "essence [Wesen]" and "first origination [ersten Entstehung]"), a criticism which implies rejection of the theory of random mutation. Hartmann does accept however Darwin's theory of natural selection in the struggle for existence, as a teleology-subordinated mechanism devised by the Unconscious (PU II (C), 314ff [II (C), 236ff] and 330 [II (C), 250]).

${ }^{20}$ PU III (C), 143-4 [II (C), 412-13]. On the ancestry of this idea, see Alexander Gode-von Aesch, Natural Science in German Romanticism (Columbia University Press: New York, 1941), ch. VI.

${ }^{21}$ Showing how discreditable this assumption could appear by Hartmann's time, see Lange, Geschichte des Materialismus. Und Kritik Seiner Bedeutung In Der Gegenwart (Leipzig: Baedeker, 1896 [first pub. 1865]), Buch 2, 279-81 [The History of Materialism, and Criticism of its Present Importance, 3rd edn, trans. Ernest Chester Thomas (London: Routledge \& Kegan Paul, 1950), bk. II, sect. 2, ch. 4, 74$5]$.

${ }^{22}$ Geschichte des Materialismus, Buch 2, 278 [History of Materialism, bk. II, sect. 2, ch. 4, 72]. Lange criticises the formal argument from probability (Geschichte des Materialismus, Buch 2, 281-3 [History of Materialism, bk. II, sect. 2, ch. 4, 75-9]) that Hartmann presents in PU I, 45-51 [I, 38-46]. Lange is typical of Hartmann's contemporaries in dismissing his claim to scientificity: see Geschichte des Materialismus, Buch 2, 80 Anm. 87 [History of Materialism, bk. II, sect. 2, ch. 4, 80 n87].

${ }^{23}$ Psychologie vom empirischen Standpunkt, Bd. 1, hrsg. Oskar Kraus (Leipzig: Meiner, 1924), 162 [Psychology from an Empirical Standpoint, ed. Oskar Kraus, trans. Antos C. Rancurello, Dailey Burnham Terrell, and Linda L. McAlister (London: Routledge and Kegan Paul, 1973), 116].

${ }^{24}$ PU II (C), 175 [II (C), 114]. See the analysis of matter in PU II (C), ch. V.

${ }^{25}$ PU II (C), 178-80 [II (C), 117-19].

${ }^{26}$ See PU II (C), ch. VII and PU III (C), ch. XIV, esp. 124-5 [II (C), 395-6]. 
${ }^{27}$ Which leaves a gap in Hartmann's reasoning (common also to physico-theological arguments for monotheism): Hartmann talks of the all-one Unconscious in a way that suggests its necessary unicity, a claim which cannot be sustained on a finite a posteriori basis. For this reason Hartmann turns in PU II (C), ch. VII, to other grounds for monism.

${ }^{28}$ Hartmann makes this distinction clear at PU I, 4-5 [I, 3-4]; see also Vorwort zur 12en. Auflage [I, xxxviii]. Hartmann's distinction does not correspond to Carus' distinction of 'absolute' and 'relative' unconsciousnesses, which is closer to Freud's distinction, in individual psychology, of Ucs. and Pcs. or of levels within the Es; see Carl Gustav Carus, Psyche. Zur Entwicklungsgeschichte der Seele (Pforzheim: Flammer und Hoffmann, 1846), 66ff [Extracts from Part I translated as Psyche: On the Development of the Soul (Dallas: Spring, 1989), 52ff].

${ }^{29}$ See PU I, 38 [I, 32-3].

${ }^{30}$ Though some overlap is to be noted: see, e.g., Carus' comments on the body's self-healing, Psyche, 92-5 [Psyche (Eng.), 70-2]. On the evidential basis of Carus' philosophy, see Mathew Bell's contribution to this volume.

${ }^{31}$ Clear statements are found at PU I, 44 [I, 37]; PU I (B), 291-2 [I (B), 252]; PU I (A), 126 [I (A), 108]; and PU II (C), 81 [II (C), 32].

${ }^{32}$ To be sure, Hartmann associates the Philosophy of the Unconscious with mysticism, but in a way that implies the latter's deflation: see PU I (B), ch. IX, which concedes nothing to mysticism that a Hegelian would not be happy to allow it.

${ }^{33}$ PU II (C), 247 [II (C), 177]. Hartmann reasserts Carus' idea that that which is unconscious for us is “super-conscious [überbewusste]” for itself (PU II (C), 247 [II (C), 177] and 258 [II (C), 186]), but this entails no new form of rationality.

${ }^{34}$ Brentano claims exactly the contrary (Psychologie, 150 [Psychology, 107]). To the extent that Brentano has Hartmann's "relative" unconscious in mind, this is a mistake, which appears to result 
from Brentano's confusion (see Psychologie, 151-2 [Psychology, 108]) either of the question of homogeneity/heterogeneity with that of psychological/metaphysical status, or of the relative with the absolute Unconscious.

${ }^{35}$ See PU II (C), 338 [II (C), 257], and Vorwort zur 12en. Auflage [I, xlv].

${ }^{36} \mathrm{PU}$ II (C), 55 [II (C), 10].

${ }^{37}$ PU II (C), ch. I, differentiates the absolute Unconscious from consciousness; PU I (B), ch. XI, differentiates the relative unconsciousness from consciousness.

${ }^{38}$ This point is connected with the fact that, whereas for Freud the unconscious is aligned explanatorily with cases of irrationality and abnormality, the opposite is true for Hartmann: the unconscious is tailored to explain the normal case. See Hartmann's remarks on the mental diseases, PU I (A), 164-5 [I (A), 141-2].

${ }^{39}$ See my "Psychoanalysis and the Personal/Sub-Personal Distinction", Philosophical Explorations 3 (2000): 96-119.

40 “die Leistung des Unbewussten ist gleichsam ein Geschenk der Götter, und der Mensch nur ihr begünstigter Bote”, PU I (B), 40 [I (B), 357]. The marked tendency of the Philosophy of the Unconscious is to rub out the line separating the personal from the sub-personal and to identify the I or person with, as he puts it on PU I (A), 78 [I (A), 67], an "indivisible spiritual-corporeal organism [einheitlichen geistig-leiblichen Organismus]", within which the conscious/unconscious distinction is not of ultimate importance. G. Stanley Hall, Founders of Modern Psychology (New York: D. Appleton and Co., 1924), 186, excogitating Hartmann, writes: "We will, e.g., to move the foot and it is as correct to say it is moved for us as that it is moved by us. It is done, we know not how, or by what agency." Hartmann's derogation of the "I" and self-consciousness is explicit at PU II (C), 78-9 [II (C), 29-30] and 108-13 [II (C), 56-60]. See Hartmann's neurological reduction of the unity of consciousness, PU II (C), 113-18 [II (C), 60-4], and rejection of free will, PU II (B), 1-2 [I (B), 322]. Carus by contrast is a 
(Leibnizian) realist about the individual self-conscious self and its freedom: see Psyche, Teil I, $71 \mathrm{ff}$ [Psyche (Eng.), 55ff], and Teil II.

41 This point is brought out if Harmann is contrasted with the later, Freud-influenced figure of Georg Groddeck, whose Das Buch vom Es. Psychoanalytische Briefe an eine Freundin (Leipzig:

Internationaler Psychoanalytischer Verlag, 1923) revolves around the very same conceptual figure as Hartmann - viz. the idea of our being inhabited and through-penetrated by an impersonal, transindividual agency - but who connects this agency tightly with the specific explanation of irrational phenomena in human life.

${ }^{42}$ Hartmann offers detailed accounts of his relations to his predecessors, PU I, 16-42 [I, 13-35] and PU III (C), 147-59 [II (C), 416-26].

${ }^{43}$ Hartmann says that the principle of the Unconscious has been arrived at by a gradual historical process and that PU has only asserted plainly and shown the significance of this principle, and by no means aired it as "a brand-new discovery [funkelnagelneue Entdeckung]” (PU I, Addenda, 295-6 [I, Nachträge, 444]).

${ }^{44}$ PU III (C), 134 [II (C), 403-4].

45 The Hegel-Schopenhauer synthesis is referred to repeatedly: see PU I, 4-5 [I, 4-5]; PU I, 27ff [I, 23ff]; PU I (A), 117-25 [I (A), 100-7]; PU II (C), 55-61 [II (C), 10-15]; PU II (C), 181 [II (C), 119-20]; PU II (C), 333-4 [II (C), 253-4]; PU III (C), 126 [II (C), 396-7]; PU III (C), 147 [II (C), 416]; PU III (C), 150ff [II (C), 418ff]; PU III (C), 165 [II (C), 431-2].

${ }^{46}$ See PU III (C), 125-6 [II (C), 396-7], and (C), ch. XII.

${ }^{47}$ Until, presumably, the process repeats itself: see PU III (C), 171-3 [II (C), 437-9].

${ }^{48}$ See PU III (C), 156 [II (C), 423], and Schelling's Positive Philosophie als Einheit von Hegel und Schopenhauer (Berlin: Otto Loewenstein, 1869), e.g. 4. 
${ }^{49}$ See PU III (C), 165 [II (C), 431] and 182 [II (C), 446]. This late Schellingian form of explanation is in Carus too, with the difference that Carus, in neo-platonic fashion, attributes to the Idea an immediate “desire for existence [Werdelust]": Psyche, 52-6 [Psyche (Eng.), 43-5].

${ }^{50}$ PU III (C), 161ff [II (C), 428ff].

${ }^{51}$ PU III (C), 154 [II (C), 422].

${ }^{52}$ Hartmann's exposition of the synthesis story is mainly in PU II (C), ch. VIII, and PU III (C), chs. XIV-XV [II (C), chs. XIV-XV]. There is a hint in Carus too of Hartmann's sexualisation: see Psyche, 62 [Psyche (Eng.), 49].

53 “die Spitze der Pyramide der inductiven Erkenntniss"; PU III (C), 146 [II (C), 415].

${ }^{54}$ Exposited at great length in PU III (C), ch. XIII. See also PU III (C), 124-5 [II (C), 395], where the normative repugnance of Will in the eyes of Idea is flatly reduced to a hedonic matter. Hartmann's commitment to hedonistic consequentialism is explicit at PU II (C), 364-5 [II (C), 280-1]. ${ }^{55}$ PU II (C), 86 [II (C), 36].

${ }^{56}$ In PU III (C), 187-97 [II (C), 451-60]), Hartmann makes a very late attempt to recast his dualism in monistic form, affirming that his model is Spinoza, and that Will and Idea are distinct attributes of a single substantial whole. This however fails to convince, if only because of the difficulty of understanding what meaningful conceptions of "substance" and "attribute" could be in play here. ${ }^{57}$ Hartmann himself states the problem, in one of its several possible formulations, at PU III (C), 165 [II (C), 431-2]; his solution is to posit a condition intermediate between potentiality and act. ${ }^{58}$ See e.g. PU III (C), 124-5 [II (C), 396-7].

${ }^{59}$ As Hartmann puts it, on his conception Will is reason's "negative of itself [das Negative ihrer selbst]" (PU III (C), 151 [II (C), 419]). Hartmann's pessimism requires this strong construal of the distinction. 
${ }^{60}$ See the talk at PU III (C), 124-5 [II (C), 396-7], of "mischief done by the irrational Will [was der unvernünftige Wille schlecht gemacht hat]", which is "guilty of the "That" of the world [schuld ist an dem "Dass" der Welt]".

${ }^{61}$ As Wilhelm Windelband observes, in Hartmann "Hegel has triumphed over Schopenhauer [hat Hegel über Schopenhauer gesiegt]", Lehrbuch der Geschichte der Philosophie, 3e. Auflage (Tübingen u. Leipzig: J. C. B. Mohr, 1903), §46, 547 [A History of Philosophy, trans. James H. Tufts (New York: Harper \& Row, 1958), vol. 2, 674].

${ }^{62}$ Contra Hartmann's assertion that the existence of the world was decided by "the act of a blind will illuminated by no ray of rational intelligence [durch den Act eines blinden, von keinem Lichtstrahl der vernünftigen Intelligenz erhellten Willens]" (PU II (C), 273 [II (C), 200]).

${ }^{63}$ PU II (C), 59 [II (C), 13].

${ }^{64} \mathrm{PU}$ II (C), 58-9 [II (C), 13].

${ }^{65}$ Hartmann comes closest to discussing this problem at PU II (C), 257 [II (C), 185].

${ }^{66}$ See, e.g., N. Kurt, Wahrheit und Dichtung in den Hauptlehren Eduard von Hartmann's (Leipzig: Friedrich Fleischer, 1894), 24ff, and Julius Bahnsen, in Der Widerspruch im Wissen und Wesen der Welt. Princip und Einzelbewährung der Realdialektik, 2 Bde. (Berlin: Theobald Grieben, 1880), Bd. 2, 209.

${ }^{67}$ For a selection of Hartmann's criticisms of Schelling, see PU I, 24-6 [I, 20-3]; PU II (C), 333 [II (C), 253]; PU III (C), 156-9 [II (C), 423-6]. Of Hegel: PU I, 27-9 [I, 23-4]; PU II (C), 333-4 [II (C), 253-4]; PU III (C), 150-5 [II (C), 418-23]. Of Schopenhauer: PU I, 29-31 [I, 24-6]; PU I (A), 117-19 [I (A), 101-2]; PU II (C), 339-43 [II (C), 258-61]; PU III (C), 149-51 [II (C), 418-19].

${ }^{68}$ Hartmann claims to be Critical, but appears to confound this with being fallibilistic and probabilistic: see Neukantianismus, Schopenhauerianismus und Hegelianismus in ihrer Stellung zu den philosophischen Aufgaben der Gegenwart (Berlin: Carl Dunker, 1877), 28. Hartmann rejects self- 
consciousness as a principle of philosophical explanation: see, e.g., his objection to Lotze's putting "Fürsichsein" in place of "Wille”, in Lotze's Philosophie (Leipzig: Wilhelm Friedrich, 1888), $156 \mathrm{ff}$. Heinz Heinrichs, in Die Theorie des Unbewußten in der Psychologie von Eduard von Hartmann (Bonn: Verein Studentenwohl, 1933), 28ff, diagnoses Hartmann's errors as stemming from his inadequate conception of the Ich.

69 “... bleibt es bemerkenswerth, dass schon so bald nach dem Feldzuge unsrer Materialisten gegen die gesammte Philosophie ein System bedeutenden Anklang finden konnte, welches sich zu den positiven Wissenschaften in einen schrofferen Gegensatz stellt als irgend eines der früheren, und welches in dieser Beziehung alle Fehler eines Schelling und Hegel in weit gröberer und handgreiflicherer Form wiederholt”, Geschichte Des Materialismus, 283-4 [History of Materialism, bk. II, sect. 2, ch. 4, 79$80]$ s.

${ }^{70}$ Lehrbuch, §46, 546 [A History of Philosophy, vol. 2, 673]. Windelband was not exaggerating Hartmann's success: studies devoted to Hartmann, in English and German, appeared regularly from the 1870 s right into the early twentieth century; according to one source, the number in 1892 stood at "over 1000” (Hartmann, The Sexes Compared and other Essays, trans. A. Kenner [London: Swan Sonnenschein, 1895], Translator's Preface, iii).

${ }^{71}$ Hartmann describes the solution of ethical problems as the "most important test for the verifying" of philosophical systems, PU I, Preface to 8th edn, xxx.

${ }^{72}$ See Hartmann, Die Religion des Geistes (Berlin: Carl Duncker, 1882) [The Religion of the Future, trans. Ernest Dare (London: W. Stewart \& Co. 1886)]. Hartmann describes himself as synthesising the Christian and Indian religions (PU I, Preface to 9th edn, xxxvii), and his philosophy as the philosophical "purification [Begriffsläuterung]” of theism (PU II (C), 271 [II (C), 198]). ${ }^{73}$ See PU III (C), 123-4 [II (C), 394-5], where Hartmann identifies the Good strictly with a state of happiness. Hartmann's claim that what really matters most to us is the beatitude of the super-human 
Idea reflects his repudiation of the first-person standpoint; this Hartmann tends to identify with egoism, and so supposes it to be overcome through the rejection of egoism: see PU III (C), 133-4 [II (C), 4023]. For a summary of Hartmann's ethical and political argument, see W. Caldwell, "Von Hartmann's Moral and Social Philosophy I - The Positive Ethic", and "Von Hartmann's Moral and Social Philosophy II - The Metaphysic”, Philosophical Review 8 (1899): 589-603 and 465-483; see esp. 594, regarding Hartmann's claim that I should identify myself with God for the sake of God's happiness. 74 “Dank der Mode ebenso oben-auf als unten-durch sind”, Jenseits von Gut und Böse. Vorspiel einer Philosophie der Zukunft, §204, in Werke: Kritische Gesamtausgabe, ed. Giorgio Colli and Mazzino Montinari (Berlin: de Gruyter, 1967-), Bd. VI, Abt. 2, 135 [Beyond Good and Evil: Prelude to a Philosophy of the Future, trans. Walter Kaufmann (New York: Vintage, 1966), 123].

75 Ibid: “das sind ja allesammt Überwundene und unter die Botmässigkeit der Wissenschaft Zurückgebrachte, welche irgendwann einmal mehr von sich gewollt haben, ohne ein Recht zu diesem “mehr” und seiner Verantwortlichkeit zu haben — und die jetzt, ehrsam, ingrimmig, rachsüchtig, den Unglauben an die Herren-Aufgabe und Herrschaftlichkeit der Philosophie mit Wort und That repräsentiren."

${ }^{76}$ From Nachlaß 1873, in Werke, Bd. III, Abt. 4, 331 [Philosophy and Truth: Selections from Nietzsche's Notebooks of the Early 1870s, ed. and trans. Daniel Breazeale (Atlantic Highlands, N. J.: Humanities Press, 1979), 101].

${ }^{77}$ As Hartmann himself put it: his work fed "a fierce philosophical hunger on the part of the public at large, concealed beneath the extreme apathy in regard to philosophical enquiries" (PU I, Preface to 7th edn, $\mathrm{xx})$. 